\title{
Marginalization of "the Other": Gender Discrimination in Dystopian Visions by Feminist Science Fiction Authors
}

\section{ABSTRACT}

In patriarchy women are frequently perceived as "the other" and as such they are subject to discrimination and marginalization. The androcentric character of patriarchy inherently confines women to the fringes of society. Undeniably, this was the case in Western culture throughout most of the twentieth century, before the social transformation triggered by the feminist movement enabled women to access spheres previously unavailable to them. Feminist science fiction of the 1970s, like feminism, attempted to challenge the patriarchal status quo in which gender-based discrimination against women was the norm. Thus, authors expressed, in a fictionalized form, the same issues that constituted the primary concerns of feminism in its second wave.

As feminist science fiction is an imaginative genre, the critique of the abuses of the twentieth-century patriarchy is usually developed in defamiliarized, unreal settings. Consequently, current problems are recontextualized, a technique which is meant to give the reader a new perspective on certain aspects of life they might otherwise take for granted, such as the inadequacies of patriarchy and women's marginality in society.

Yet there are authors who consider the real world dystopian enough to be used as a setting for their novels. This is the case with Woman on the Edge of Time by Marge Piercy and The Female Man by Joanna Russ. Both texts split the narrative into a science fictional and a realistic strand so as to contrast the contemporary world with utopian and dystopian alternatives. Both texts are largely politicized as they expose and challenge the marginalized status of women in the American society of the 1970s. They explore the process of constructing marginalized identities, as well as the forms that marginalization takes in the society. Most importantly, they indicate the necessity of decisive steps being taken to improve the situation. 
Sex-based discrimination is the most widespread form of social oppression, since the criterion of gender is readily applied in delineating social division lines. According to feminists, this has led to the establishment of the patriarchal system, defined as a political institution "whereby the half of the populace which is female is controlled by that half which is male" (Millett 34). Such a dichotomization is a direct result of the dualistic thinking of the phallocentric society, in which the core of the system of thought and of the society as a whole is embedded in oppositional binarism. A relationship which remains in a binary opposition inherently entails a strong contrast and a superiority relationship. Inevitably, thus, "the other" is ascribed an inferior rank, along with features opposite to those exhibited by the superior norm. The male and the female in the patriarchyshaped consciousness are representative of such a relationship, in which the woman is "the other," who frequently assumes marginalized status.

This marginality is closely associated with a strong sense of difference resulting from the decidedly androcentric perception of gender. Significantly, femininity can even be defined in terms of a marginalized social position. Following Julia Kristeva, Toril Moi describes femininity as "that which is marginalized by the patriarchal symbolic order" (248). Thus, it seems undeniable that gender is one of the main determinants of marginality (Lee 33), and that women are the most frequent victims of marginalization. This fact manifests itself primarily in exclusion from social and economic life, denial of freedoms and lack of equality. Invariably, patriarchy is the instrument of social control, which ensures that this state of affairs persists, as it "[keeps] women out or on the edges of its economy and institutions" (Heath qtd. in Barr 70).

The marginalized status of women has been one of the main preoccupations of all the waves of feminism, the first two in particular. While feminist philosophy addresses the problem from a socio-political perspective, feminist science fiction attempts to approach it from a literary angle. A marginal genre in itself, feminist speculative fiction discusses the same issues that concern feminist theorists, yet it presents and dramatizes them in the form of thought experiments. The negative aspects of patriarchy, including the marginalization of women, are typically exposed by means of dystopian visions. Masculinist dystopias feature worlds of male dominance, where discrimination and sexism are carried to the extreme. These are usually set in invented worlds, planets, moons and lands, the exact spatial and temporal location of which remains unknown. Despite this or, paradoxically, due to this intentional cognitive estrangement, the problems dramatized in such novels are recognizable for a contemporary 
reader. Indeed, many critics perceive strong parallels with the contemporary world, which can hardly be dismissed as unintended. Even though certain issues are exaggerated, their relevance to current issues is indisputable.

Thus, defamiliarization and the introduction of fantastic elements do not detract from the social significance of feminist science fiction and they certainly do not lessen their impact on its target audience. Still, many authors opt for more straightforward ways of social indictment than merely criticism by implication. They rely on realist techniques to convey the message about the deficiencies of our world and its social organization, in particular the continued inequality of women. Consequently, instead of otherworldly locations and extraterrestrial races, the reader is presented with a more or less traditionally realist, or even naturalist, depiction of twentieth-century America-contemporary to the authors at the time of writing. This allows the writers to illustrate truthfully, without the guise of science fictional tropes, the actual gender inequality that they wish to disclose as prevalent and harmful.

The two most significant texts of this kind are both feminist utopian classics-Woman on the Edge of Time by Marge Piercy and The Female Man by Joanna Russ. The action of both novels is set in the same year, 1976 . Therefore, they can be seen as a literary response to what second-wave feminists indentified as the oppressive and limiting social environment of the 1970s. Also, both texts combine utopian and dystopian elements as they juxtapose a utopian alternative with the flawed contemporary society. Interestingly, both envision the utopia to be located in our future, rather than on a distant island or planet as the stock utopian convention would have it. Thus, it is not spatial but temporal distance that separates us from the utopia and the conclusion is that it can only be reached if the right choices are made in the present. The depiction of future worlds as well as the use of the time travel theme are fantastic elements, which categorize the novels as science fiction works. However, these speculative components exist side by side with close social observation.

In fact, Woman on the Edge of Time is frequently described as a work of social realism (Makinen 17). However, it is also defined as "a successful blending of realistic and speculative modes" (Walker 17), which points to its genre variety. The plot centres on a female character, Connie, who experiences all the negative aspects of contemporary America-she lives in "a wild zone of dispossession and contempt" (Berkson 111). Even though she is described as a typical utopian traveller, she departs from the pattern as her journey to utopia is a consequence of time travelling, or, as Dana Fancourt sees it, of mental travelling (99). Connie accesses utopia through what Fancourt defines as "altered states of consciousness" (100). Indeed, it 
is only her mind that is transferred to the future, with her body remaining in her own time.

The society she visits is the future community of Mattapoisett, a place of absolute equality. The strong contrast between the two primary settings stems from the fact that Connie's own life is a story of failure and abuse, all resulting from her being female in a patriarchal society. Marleen Barr makes the chilling observation that Connie's suffering is not purely fictional but is actually shared by many women in America (74). Connie's discrimination takes place on three levels: that of gender, class and race, all of which constitute the grounds for her social oppression (Makinen 17) but also "the determinants of power" in a patriarchal society (Bammer 96). Katherine Payant considers Connie the apotheosis of a victim of capitalist patriarchy, representing the abuse endured by social groups such as "women, ethnic minorities, the poor, the uneducated, the old" (66), all suffering from the effects of marginalization. Connie can therefore be perceived as the ultimate "other"-she is everything that a white Anglo-Saxon upper-class male is taught to despise, his absolute opposite. Not only is Connie a female, but also a Chicana from a poor immigrant family. Her underprivileged status is aggravated by her aborted pregnancies, a failed attempt to gain a college education and her history of criminal activity and child abuse. At the novel's start, she is on welfare, she has lost custody of her daughter and she is about to be hospitalized in a mental institution. She is thus an outcast in every sense of this word-she is racially, socially and sexually estranged from the mainstream society. Even though her social status renders Connie "an unlikely heroine" (Green), it is precisely what enables the author to use this character to expose and denounce the abuses of patriarchy.

All the calamities that fall upon Connie can be traced back to the men who have come her way. In fact, her life is a catalogue of unfortunate relationships with men, beginning with her father, and continuing with her brother, her college professor, her husbands, partners and her doctors. Connie's plans to "be someone" (Piercy 46) fail as she becomes pregnant by a white student who disclaims any responsibility for the child. The woman decides to have an illegal abortion, done "without anaesthetic" (Piercy 234). Her family disown her and Connie describes herself as a "spoiled woman:" "Neither baby nor husband, neither diploma, nor home. No name. Nobody" (Piercy 234). Connie is not only "spoiled," she is also a nobody in social terms-her whole existence is negated and for her family and the society she becomes a nobody. Connie's predicament exposes the sharp contrast between America and Mattapoisett. In Mattapoisett live birth has been eliminated and the responsibility for children is shared. In the twentieth-century patriarchy it is women who take 
the brunt of unwanted pregnancies. Connie's two aborted pregnancies are shown to have been a burden to her. The first one cost Connie her college education, which, according to Michael, reveals that reproduction assists Western culture in limiting women and in thwarting their potential (11). What is more, since Connie's disadvantaged status in the society results in the immediate removal of her daughter from her custody and placing her with a white family who benefit from Connie's misfortunes, she can also be described as a "reproductive machine" (Barr 75).

During her college education Connie is used not only by her boyfriend, but also by one of the professors, who hires her as a secretary, or rather "secretary-mistress" as Connie blatantly puts it. What Connie feels recalling this liaison is what she calls "the anger of the weak" (50)—an anger that can never find an outlet as nobody sympathizes with the suffering of the weak and the poor, whose pain is never brought to light. Connie recalls with bitter irony that Professor Silvester "liked to have a Spanishspeaking secretary, that is, a new one every year-dismissed when he went away for summer vacation. He called them all Chiquita, like bananas" (50). The professor, representing the characteristic features of an educated and respected WASP, objectifies his secretaries, which is evident in denying them the right to be called by their own names. They are all products easily identifiable by a brand name, disposed of as soon as the professor is ready to dispense with their services-the sexual ones rather than the secretarial.

As for Connie's two husbands, only the first offers her true affection, yet he is killed in race riots. The circumstances of his death are very telling. Piercy shows that both gender polarization and racial intolerance lead to oppression and violence. Connie's second husband, Eddie, is a wife batterer, who eventually abandons Connie and her small child. Subsequently, Connie partners with Claud-a black saxophone player and a pickpocket. Though described as a caring man, he is guilty of drawing Connie into the world of crime. After he dies in prison Connie suffers from severe depression and becomes an alcoholic. Consequently, she neglects her daughter, Angelina, and hits her in a drunken fit. As a result she is declared unstable and unfit for mothering and her daughter is placed with a foster family. Significantly, the fostered family is white-the social worker comments that finding a family for her will be easy due to the child's relatively light skin. Thus, in capitalism, even the child is objectified and treated like a product. She is of interest to a well-off American family because she fulfills the requirements that they have set for the prospective child. Moreover, ethnic origin emerges here as a crucial factor determining one's progress from marginality to the mainstream.

After this violent incident Connie is institutionalized for the first time. The same happens again when she assaults her niece's pimp, Geraldo. 
Even though she acts in Dolly's defense, she is not believed and Geraldo's testimony is taken as more credible by the authorities than Connie's words. This is yet another example of how a woman's voice is stifled and male authority is recognized. Another man who has the final word in committing Connie to the hospital is her brother, Luis. Luis is eager to have Connie shut out of sight as he is ashamed of his humble origins as the son of Mexican immigrants, which he considers to be the potential source of his own marginality. He dreams of social advancement, which is only possible if one submits to the rules of mainstream America. His efforts to establish his Anglo image culminate in the choice of his three wives, each of whom is to reflect his current status. Altogether, they mark Luis's progress towards the desired social position: they advance from a Puerto Rican to a WASP. Connie notes that "all Luis's wives came to sound the same, nodding at him, but each one was fancier and had a higher polish" (33). Thus, what Luis's successive marriages amount to is basically a product updateuntil the most desirable model is obtained. Even though he rejects his Mexican heritage and poses as a mainstream American, it is also clear that he moulds his wives to behave in the Mexican manner "passive ... dressed in black with ... eyes downcast, never speaking until addressed" (Piercy 43). Women who are ethnic minorities are thus presented to be suffering from double marginalization-within the society and within their own households.

Connie finds herself at the mercy of men such as Luis and Geraldo. She is aware of her own powerlessness and vulnerability in the maledominated world: "All my life I been pushed around by my father, by my brother Luis, by schools, by bosses, by cops, by doctors, and lawyers and caseworkers and pimps and landlords. By anybody who could push" (98). Connie's evaluation of her life is highly negative-she perceives her own status as a victim and she also denounces the society's tendency to control, dominate and subdue all those who are unable or unwilling to fight back. Connie's resentment at such treatment is clearly directed at the male part of the society. In fact, in Geraldo, Connie discerns the reflection of all the abusive men she encountered in her life: "[he] was her father, who had beaten her every week of her childhood. Her second husband, who had sent her into emergency with blood running down her legs. He was el Muro, who had raped her and then beaten her because she would not lie and say she had enjoyed it" (Piercy 51).

Connie was conditioned into accepting abuse due to the domestic violence that she experienced on a regular basis as a child. This damaged her self-esteem and made her unable to control her own life and eventually caused her to strike her own daughter. Connie has been made into a patriarchal pawn-she realizes that she is merely a thing, with which men are 
free to do whatever they like. Her awareness of her own objectified status is clear in the frequent descriptions of herself in terms of things: "an object" (302), "a bag full of pain and trouble" (41), "human garbage carried to the dump" (32). This latter image and the invocation of waste disposal is a recurrent motif in masculinist dystopias. The "dump" is the mental asylum, where "little is recycled" (Piercy 32). Other undesired elements kept within the institution include, in Connie's words, "[those] who caught like rough teeth in the cogwheels, who had no place or fit crosswise the one they were hammered into" (31). The machinery imagery points to the dehumanization of social outcasts as well as to the soulless, mechanical character of the society, in which elements that fail to interlock within the apparatus are promptly discarded.

Another aspect that Connie's institutionalization dramatizes is the readiness with which the woman is labelled insane. Keith Booker and Anne-Marie Thomas remark that it is not uncommon for a woman to be described as neurotic if she acts against the expectations of the society. This is especially valid in the case of women who resort to violence or challenge the status of women under patriarchy (243). A similar opinion is voiced by Magali Michael, who considers the insanity diagnosis in cases such as Connie's a label that ensures the hegemony of males (131). Needless to say, it legitimizes women's confinement to the social margins. Indeed, those whom Connie befriends in the hospital are all misfits. Sybil is "persecuted for being a practicing witch, ... for encouraging [women] to leave their husbands" (Piercy 84). Moreover, as is typical of patriarchal critics, she denounces sex with penetration and sex in general: "who wants to be a dumb hole? ... do you want to be a dumb hole people push things in or rub against?" (85). Sybil believes that by refusing to have sex life she makes her first step towards disobjectification-she ceases to be a mere hole, a thing.

Many of the patients in the text undergo experimental treatment intended to eradicate socially unacceptable patterns of behaviour. Connie is subjected to the procedure as well, which in her case involves placing electrodes in her head in order to modify her conduct. In a very meaningful manner, the description of the operation is full of images of penetration: "First Dr. Redding drilled on her skull ... she could feel the pressure, she could feel the bone giving way, she could hear the drill entering. Then she saw them take up a needle to insert something ... [into] her penetrated brain" (281). This mental and medical rape is one of many references to this manner of domination in the text. In fact, rape can be seen as "a prevalent metaphor to describe society's violent manipulation of those it considers marginal” (Michael 11).

Apart from the electrode implantation and the actual rape that Connie endured, she also experienced another incident of medical violation. When 
she was admitted into hospital with a hemorrhage after an illegal abortion and the beating by Eddie, doctors performed a totally unnecessary hysterectomy, because "residents wanted practice" (Piercy 14). Connie feels that by this violation she was deprived of her femininity. Similarly, the brain implantation procedure, which is to control Connie's emotions, is perceived by Connie to be an attempt to erase her female sensitivity and perspective. She senses that for the doctors, her uncontrollable female emotions are nothing but "a disease ... to be cut out like a rotten appendix" (282). The comparison to a surgical intervention indicates that Connie associates both the loss of her womb and the medical manipulation of her brain with an attempt to deprive her of her womanhood. She strongly resents the male doctors for these attempts. She describes them as "cold, calculating, ambitious, believing themselves rational and superior, [chasing] the crouching female animal through the brain with a scalpel" (282). In this quotation it is evident that Connie is subconsciously aware of the harmfulness of binary thinking which categorizes the woman as "the other." Men are associated with reason and mental stability, while the woman is "a crouching female animal," unpredictable and wild. Connie is the hunted animal, not only "the other," but a fourfold "other" as Magali Michael defines her, taking into consideration not only her ethnicity, gender and poverty but also her advancing age (114). She perfectly fits Lucy Sargisson's definition of "the other" - she is "marked by difference ... the stranger, the alien" (147). Being "the other," Connie is feared and detested, and consequently, she is abused by men who are unable to accept the difference.

Connie's distrust of white doctors and scientists is also evident when she recollects her sister's negative experience with such men. After having given birth to her sixth child, she went to a clinic to obtain contraceptive pills; however, she was given sugar pills instead. As a result, she became pregnant with another child, who was born mentally handicapped. Connie reflects that doctors and scientists "like to try out medicine on poor people. Especially brown people and black people. Inmates in prison too" (27). In fact, medical experiments and infection with hepatitis resulted in the death of one of the two men she truly loved, the black pickpocket, Claud. These examples prove the point that Tatiana Teslenko makes about Piercy disclosing "medical paternalism towards marginalized groups, such as all women, all people of colour, and especially poor women of colour" (66).

In Mattapoisett Connie discovers an alternative to the bleak existence in the world where "it [is] a crime to be born poor as it [is] a crime to be born brown" (Piercy 62). Here, all the problematic issues that affect Connie's situation are resolved. However, the text makes it clear that the utopian future is not a given-it is conditional on the conscious efforts of the 
contemporary people, who are the only ones who can bring it into being. Piercy shows that "present actions create future probabilities" (Walker 19) and that utopia is a matter of a conscious choice-to fight against patriarchy (Booker and Thomas 243). Connie realizes that the only way to fight patriarchal oppression and to overcome her marginality is open resistance. In an act of ultimate rebellion and defiance she poisons the doctors who treat her. While numerous critics see it as an empowering deed and the final liberation (Jones 12), others are critical of the fact that violence is presented as a solution to the abuses of a system in which violence is a prevalent problem (Maciunas 257). Still, on the other hand, Connie is severely restricted in the choices of action available to her. Her decision to exact punishment upon those who mistreated her is the first moment in her life when she resolves not to be "pushed around" any more. She reflects that "at least once [she] fought and won" (370), and she considers her act a winning battle in an ongoing war against patriarchy that will eventually allow Mattapoisett to arise. Even if the ending is controversial, the overall message is clear: Piercy calls for radical political action to reform the society and cure it of its current ills.

The conditional availability of the utopian alternative is also characteristic of The Female Man by Joanna Russ. It also features a future world-Whileaway-which is separated from the contemporary society by ten centuries. Even the name of the future utopia suggests temporal distance-it is a place that is a while away from here rather than remote spatially. Both Russ's and Piercy's texts emphasize the need to confront the patriarchal system and both constitute cautionary tales (Walker 179), due to their dystopian presentation of contemporary America and the critique of the direction in which it was progressing in the 1970s.

The Female Man features a "cluster protagonist" (Bartkowski 4), signified by the fact that all of the four characters bear names beginning with the letter "J." The four women depicted by Russ are all versions of the same woman and are identical genetically. What differentiates them is their socially-constructed gender and female subjectivity. Janet comes from an all-female world, hence she never faced the necessity of defining herself in relation to men and their expectations. She is thus confident and independent. Jael lives in a dystopian world in which gender separatism has been taken to an extreme-men and women inhabit separate spheres and are in a constant state of violent war with each other. She is fierce and unbending, especially in relation to men. Her strong misandric attitudes culminate in ruthless androcidal acts that she perpetrates on men. Jeannine's and Joanna's worlds are the closest to the world of the author. Yet while Jeannine is utterly subjugated to patriarchy and its demands, Joanna is ready to wage war on the system. In her anti-patriarchal sentiments she 
can be identified with the author herself (Lefanu 191), especially when the name coincidence is taken into account.

It is in Joanna's and Jeannine's worlds that the reader can see a critical analysis of social inequality pertaining to contemporary America, and the marginalization of women in particular. Jeannine is a self-effacing woman in complete submission to patriarchy, which inculcated in her an acceptance of her marginalized status and the restrictions it places upon her. She firmly believes that finding the right man to marry is the ultimate goal in the life of every reasonable woman. This mindset stems from the patriarchal socialization to which she has been subjected since the day she was born. The continuous indoctrination is a life-long process. When she turns twenty-nine and is still unmarried, her brother warns her against the worst possible plight for a woman-becoming an old spinster with no one to take care of her. She is also advised that apart from marriage "there's no other life for a woman" (114). Consequently, she surmises that in malefemale relations "his contribution is Make me feel good; her contribution is Make me exist" (120). Thus, she needs a man to give meaning to her life, as she herself is unable to make it meaningful. One of the narrators remarks that "there is some barrier between Jeannine and real life which can be removed only by a man or by marriage" (120). To put it differently, not until Jeannine assumes her proper social role can she feel fulfilled as a woman. If she does not, she will be seen to be merely "drifting" (Russ 114) in her life. Therefore, marriage is shown as the only means available to a woman willing to improve her marginalized status, however partial and illusory such an improvement might in fact be. Jeannine senses that something is wrong with her life, but she is too strongly conditioned to be able to perceive the source of her discontentment and to transform her life. This, according to Jeanne Cortiel, stems from her lack of agency and the unawareness of her oppressed situation (79).

Joanna, in turn, gains enough perspective to evaluate her life. She grows aware of the fact that "all she did was dress for The Man, smile for The Man, talk wittily to The Man, sympathize with The Man, flatter The Man, understand The Man, defer to The Man, entertain The Man, keep The Man, live for The Man" (Russ 29). The brief summary of the male-centred life reveals her frustration at the fact that men's needs are always prioritized in a patriarchal society and that the woman is nothing but a tool to satisfy them and to stabilize their "shaky egos" (Russ 202). She is able to reject the teachings of her mother who tried to explain to her why "being a girl is wonderful" (Russ 65), elucidating at the same time what it means to be a woman in this society. The female role is merely to be attractive for men and acquiescent. Only men are supposed to be active, with their women remaining forever passive and full of admiration for dar- 
ing male exploits and various successes. The mother insisted that "instead of conquering Everest [Joanna] could conquer the conqueror of Everest, and while he had to go to climb the mountain, [she] could stay at home in lazy comfort" (65). However, Joanna would much prefer to climb Everest herself rather than let men do it on their own. She reflects that "you can't imbibe someone's success by fucking them" (65). She voices here one of the concerns of second-wave feminists-women no longer wish to be the shadows of their husbands, ornaments and mirrors in which men's selflove can be reflected. Like them, Joanna feels that the social organization of her country deprives her of the right and opportunity to do anything significant, other than pursuing "a mystical fulfilment in marriage" (Russ 6) that her mother endorses. For Joanna, the "mystical fulfilment" her mother talks about is equal to "washing floors" (Russ 6).

The issue of fixed and rigid gender roles and the way that women are molded into them is one of Russ's primary concerns in the text. She questions the marital subservience of women and perceives marriage as institutionalized slavery. She tackles the problem of unpaid labour that women provide for their households as well as the husbands' unwillingness to support their wives in the decision to enter a profession. Both were key concerns of second-wave feminism, which informs much of the text. Russ mocks the men's alleged appreciation of women's work expressed in the glorification of the woman's noble calling in being Mother, spelled with a capital letter. One of the narratorial voices, Joanna, discloses the truth behind such lofty notions and denounces the task of being a mother and wife as nothing other than domestic service. She enumerates in the catalogue style that Russ often employs in The Female Man what it really means to be a mother: "to form the coming generation, to give birth to them, to nurse them, to mop floors for them, to love them, to cook for them. Clean for them, change their diapers, pick up after them, and mainly sacrifice themselves for them" (137). Such confinement to the domestic circle contributes to the women's sense of exclusion from social life. This, in turn, eventually propels them to confront their marginality and realize their potential outside the home.

However, when a woman wishes to enter the job market and prove that she can contribute both to the community and the household, she is frequently discouraged by her husband. Russ imagines a conversation that might take place between such spouses and incorporates in it the arguments that are usually cited by the opponents of women's paid work outside the home. The archetypal husband first tries to rationalize his dismissal of his wife's ambitions by saying that the cost of a baby-sitter and the tax on her income surpasses her earnings, which makes her employment pointless. When that fails he tries to coax her into accepting the view that 
she is lucky to be provided for by a loving husband. When that too comes to no effect he bluntly informs his wife: "You can't make money. Only I can make money" (188). He then accuses her of irrationality, which, as Connie's example also shows, is a common strategy. A woman not conforming is a woman erring, a woman ailing. "I am a woman with a woman's brain. I am a woman with a woman's sickness" (137), Joanna remarks, referring to her inability to accept patriarchal standards and to the fact that such a stance is frequently tagged as a mental illness. Her femininity is what makes her "the other," especially when it oversteps the boundaries imposed by patriarchy, in which her rebellious mind can only be described as "very swampy ... very rotten and badly off" (Russ 137).

In effect, Russ catalogues again, "Men succeed. Women get married. Men fail. Women get married. Men enter monasteries. Women get married. Men start wars. Women get married. Men stop them. Women get married. Dull, dull" (126). Thus, men are free to choose what they want to do with their lives, they are free to make mistakes and gain a full spectrum of human experience. Women, in turn, are denied this right and in all aspects of life they are dependent on men. Their only destiny being marriage, they live through their husbands' lives-through their successes and failures. Thus, marriage is exposed as one of the major sources of the marginalization of women. Despite its apparent role in increasing a woman's social status-unmarried women are low on the patriarchal scale-marriage ensures that women's social aspirations are kept in check.

Moreover, this finds reflection in the wider socio-political context. Women, as Joanna sarcastically comments, seem to constitute only onetenth of the society. If one considers that nearly all the doctors, lawyers, bankers, managers, police officers, government officials, soldiers etc. are male, it follows that "it's a legend that half the population of the world is female" (Russ 204). In the same mocking tone, the narrator remarks that "there are more whooping cranes in America than there are women in Congress" (61). Russ is drawing attention to the fact that in her society women are still underrepresented in many spheres of social life, primarily in politics. They can be said to be occupying what Angelika Bammer calls "the muted zone" (66), that is the lowest position on the social scale, where their voices are subdued. Russ also notices that the privileges that men enjoy are inaccessible to women, whose position in the society is only connected with numerous disadvantages (Hollinger 16).

American women in the 1970s were gradually gaining an awareness of the discrimination to which they were subjected. Also, they yearned to assume positions which were restricted to men. Joanna even admits to being "a victim of penis envy" (6). However, the sense of incompleteness arises not from the actual physical lack, but from the deprivation experienced 
in social and economic spheres. It is also not the result of the "Feminine Incompleteness" (12) that Russ enumerates as one of the desired features in a woman. Feminine Incompleteness is understood, in patriarchal terms, as the social and personal alienation that any woman yet unmarried experiences. Feminine Incompleteness must be accompanied by Maternal Instinct, which makes "forever wretched" (Russ 151) any woman not eager to have babies, and, finally, True Womanliness. The latter involves a woman's "liking male bodies" (Russ 152), always submitting her sexual needs to the male wants and preferences, never showing her intelligence and always flattering the male. Taking these standards into consideration, Joanna affirms that she is anything but a woman: "I am a telephone pole, a Martian, a rose-bed, a tree, a floor lamp, a camera, a scarecrow. I'm not a woman" (152). She denies her own womanhood as defined by the patriarchy and she decides to turn into the eponymous "female man." In order to do so, she has to reject all the roles imposed upon women-all the functions that a perfect woman ought to serve:

a self-sacrificing mother, a hot-chick, a darling daughter, women to look at, women to laugh at, women to come to for comfort, women to wash your floors and buy your groceries and cook your food and keep your children out of your hair, to work when you need the money and stay home when you don't, women to be enemies when you want a good fight, women who are sexy when you want a good lay, women who don't complain, women who don't nag or push, women who don't hate you really, women who know their job, and above all—women who lose. (Russ 195-96)

The rejection of these standards is presented as the only means by which women can challenge their social insignificance and their confinement to the fringes of society. However, any attempt to do so is invariably punished with social ostracism and the attachment of labels the stigma of which is to be feared by any woman willing to survive under patriarchy. For instance a woman seeking to earn higher degrees at university is "frigid" (Russ 20), while women who are not passive are immediately labelled as "neurotic" (Russ 20). Such tags are denounced as patriarchal tools conveniently employed to keep women in their place.

Joanna's transformation into the "female man" begins when she realizes that as long as she is a woman, she remains merely a sexual object. This is especially true in the case of women trying to succeed in a maledominated field, as Joanna did in the academic world. She remarks that if a woman does not renounce her femininity and try to be "One of the Boys," she will be eyed in the same manner as if she was "wearing a sandwich board that says: I HAVE TITS!" (133). The transformation also in- 
volves the renunciation of such feminine features as delicacy, caring, and passivity. She becomes "a ball-breaker, a man-eater [who] crack[s] [men's] joints" (Russ 13). Tatiana Teslenko comments that the transformation is enabled by "enacting anger and exercising violence against men" (167). The assimilation with men and the adoption of their aggressive attitude equalizes Joanna with them, allowing her to gain access to spheres which have traditionally been man-only sections of a patriarchal society.

Becoming a man, a female man, is her tactic to combat the system's inequality: "there is one and only one way to possess that in which we are defective, therefore that which we need, therefore that which we want. Become it" (Russ 139). The traditional association of the word "man" with "mankind" logically entails the conclusion that, being a part of the human race, a woman is male as well. Joanna summarizes: "for years I have been saying Let me in, Love me, Approve me, Define me, Regulate me, Validate me, Support me. Now I say Move over. If we are all Mankind, it follows ... that I too am a Man and not at all a Woman" (140). By becoming a "female man," Joanna escapes patriarchal bondage-this involves taking over men's duties and some of the male features. The female man has to, in Teslenko's words, appropriate "masculine virtues" (169), such as dominance and violence, which is the only way to channel their rage and to seize power from men. However, there exists a certain paradox in the advocacy of violence as a solution to patriarchal oppression, just as was present in $A$ Woman on the Edge of Time. Russ castigates masculine dominance and brutality, while simultaneously endorsing them in her depiction of the female man, who needs to assume these qualities in order to be able to begin both personal and social transformation (Teslenko 171, Cortiel 77).

The embodiment of female rage can be found in Jael, an assassin from a dystopian future. According to Nancy Walker, Jael represents "the essence of women's anger at men for centuries of subjugation" (182) as she kills men without hesitation. Jael's world is a "dystopian antithesis" (Bammer 96) to Whileaway. The inclusion of such a negative counterpart constitutes another major point of convergence with $A$ Woman on the Edge of Time. During one of Connie's mental journeys she is taken to a dystopian alternative, which exists in a world parallel to Mattapoisett. Like Jael's world it is located in the future and it represents the worst possible scenario of the earth's development. Bartkowski refers to these futures as "wrong" and "false" (61). Yet only the former seems to be accurate, as falsity is not intended by the authors as one of the characteristics of these worlds. They are very concrete and tangible, being both the possible outcomes of today's social tensions and the alternatives to the posited utopias. Their credibility and realness lie in the fact that they are shown as potential replacements for Whileaway and Mattapoisett, should such nega- 
tive transformations be allowed. Thus, they are to encourage the reader to try to avert them by conscious political effort.

The inclusion of the dystopian counterparts in both texts enables the authors to criticize the hierarchical organization of Western society in a much more explicit manner. It might seem that the presentation of the utopian alternative is not their main intention. Teslenko quotes Joanna Russ herself, who comments on utopia that "it reflects what women lack in today's patriarchal world" (168). In a very similar vein, Kerstin Shands remarks that "Piercy's intention [is] not so much to create Eden as to mourn the lack of it" (72). Thus, both authors wish to bring attention to current problems and to propel readers to political action. This is achieved by introducing solutions which are meant to defy and transcend the standards of patriarchal society, thus deconstructing binarisms which marginalize women.

However, despite the fact that the texts are aimed at subversion, transgression and deconstruction of binary notions, especially those related to gender, they do make use of binary oppositions which go along the following division lines: dystopia/utopia, patriarchy/matriarchy, male/female, subjugation/freedom and injustice/equality. Thus, maleness is identified as the source of social ills which invariably situate the woman in the position of the victimized "other." Dystopia, in turn, is associated with patriarchy and the problems it poses both in the invented worlds and in the contemporary society. It might be argued that this is a highly simplified conception of social reality, which hardly lends itself to such clear-cut divisions. What is more, the juxtaposition with a dystopian patriarchal reality may be perceived as a precondition for the very existence of utopia. To put it differently, such novels set out to combat sexual binarism and yet they are constructed upon this very antagonism-instead of rejection of the status of "the other," they construct their whole utopian structure on opposition to maleness and patriarchal norms. As a result of contrasting the utopians with patriarchal males, both novels may be seen to be operating within the framework of oppositional structures, whose binarism is not transgressed. Instead, the patriarchal valuations attached to each sex are reversed, making the dichotomy favorable to women.

Another contradiction that stems from this revision of sexual dualism is gynocentric bias, which can be traced in both novels, as they discredit male rule and promote opposing, female values. Hence, a clear tendency to valorize women and female attributes is perceptible. Russ entirely eliminates men from her utopian Whileaway, considering them the source of women's oppression and marginalization. In Piercy's text an apparently degenderized society is established, however, it suppresses what is perceived as male patterns of behavior while reinforcing feminine features, such as 
nurturance, gentleness and patience. As a result, the men of Mattapoisett are similar to women not only in mental, but also in physical terms-they are even able to breastfeed. Accordingly, the constructivist message of the texts clashes with their more or less overt essentialism. While on the one hand they denounce the patriarchal construction of gender and opt for its deconstruction, they simultaneously promote an essentialist understanding of femininity as a set of innate superior traits. Similarly, masculinity is defined in negative terms, inasmuch as men are generally shown to be prone to violence and domineering behavior. Thus, it can be posited that in the place of androcentrism and misogyny, these works sometimes display a shift, often barely perceptible, towards gynocentrism and misandry. This is especially evident in radically separatist Russ, but also, in a less explicit manner, in liberal Piercy.

Lastly, even though the novels are adamant in their critique of the marginalized status of women in America of the 1970s, no implementable solutions to this state of affairs are offered. Though both novels advocate action towards the achievement of the "not-yet" and they both present its benefits based on the examples of Mattapoisett or Whileaway, individual characters in the novels do not undertake any significant actions that might bring about social change or, at the very least, alter their own marginalized existence. Jael is a man-hater and a man-slayer; Joanna rejects her own womanhood in order to adapt to the system, rather than try to reform it from within. Jeannine is mostly unable to see beyond the reality in which her role is preestablished; and Connie resorts to murder. However liberating her androcidal act might seem, it remains highly questionable ethically. While to a large extent the women's lack of agency or their misguided attempts may be attributed to patriarchal conditioning, they cannot be completely absolved of the responsibility for their own existence.

Still, these contradictions do not detract from the novels' impact as literary voices indicative of women's dissatisfaction with their status in patriarchy. Monique Wittig calls The Female Man a "literary war machine" (qtd. in Ayres), insofar as it sets out to expose and combat the marginalizing character of patriarchal institutions. Doubtlessly, the same could be said of Woman on the Edge of Time. Connie is a woman on the edge in every possible sense of this word, as is Jeannine and even Joanna, at least until the moment of her transformation. The realism in the presentation of their peripheral role in society is successfully blended with the science fictional elements of the contrastive utopias and dystopias. In effect, this literary amalgam strengthens the novels' message regarding women's marginality and the necessity to confront it, even if the texts are deficient in actual models of individual action. 


\section{WORKS CITED}

Ayres, Susan. “The 'Straight Mind' in Russ's The Female Man.” Science Fiction Studies Website. DePauw University, n.d. Web. 1 Feb. 2011.

Bammer, Angelika. Partial Visions: Feminism and Utopianism in the 1970s. New York: Routledge, 1991. Print.

Barr, Marleen. Lost in Space: Probing Feminist Science Fiction and Beyond. Chapel Hill: U of North Carolina P, 1993. Print.

Bartkowski, Frances. Feminist Utopias. Lincoln: U of Nebraska P, 1991. Print.

Berkson, Dorothy. "So We All Became Mothers." Feminism, Utopia, and Narrative. Ed. Libby Falk Jones and Sarah Webster Goodwin. Knoxville: U of Tennessee P, 1990. 100-15. Print.

Booker, Keith M., and Anne-Marie Thomas. The Science Fiction Handbook. Singapore: Fabulous, 2009. Print.

Cortiel, Jeanne. Demand My Writing: Joanna Russ, Feminism, Science Fiction. Liverpool: Liverpool UP, 1999. Print.

Fancourt, Donna. "Accessing Utopia through Altered States of Consciousness: Three Feminist Utopian Novels." Utopian Studies 12.1 (2002): 94-107. Print.

Green, Michelle Erica. "Marge Piercy, Woman on the Edge of Time (Fawcett, 1977)." The Green Man Review. The Roots and Branches of Arts and Culture. 16 Dec. 2010. Web. 18 Jan. 2011.

Hollinger, Veronica. "'Something Like a Fiction': Speculative Intersections of Sexuality and Technology." Queer Universes: Sexualities in Science Fiction. Ed. Wendy Gay Pearson, Veronica Hollinger and Joan Gordon. Liverpool: Liverpool UP, 2010. 140-60. Print.

Jones, Libby Falk. "Gilman, Bradley, Piercy, and the Evolving Rhetoric of Feminist Utopias." Feminism, Utopia, and Narrative. Ed. Libby Falk Jones and Sarah Webster Goodwin. Knoxville: U of Tennessee P, 1990. 116-29. Print.

Lee, Jung Young. Marginality: The Key to Multicultural Theology. Minneapolis: Augsburg Fortress, 1995. Print.

Lefanu, Sarah. In the Chinks of the World Machine. Feminism and Science Fiction. London: Women's, 1998. Print.

Maciunas, Billie. "Feminist Epistemology in Piercy's Woman on the Edge of Time.” Women's Studies 20 (1992): 249-258. Macalester College. Web. 29 Jun. 2011.

Makinen, Merja. Feminist Popular Fiction. New York: Palgrave, 2001. Print.

Michael, Magali Cornier. Feminism and the Postmodern Impulse: PostWorld War II Fiction. Albany: State U of New York P, 1996. Print. 
Millett, Kate. Sexual Politics. New York: Ballantine, 1989. Print.

Moi, Toril. "Feminist, Female, Feminine." Feminisms. Ed. Sandra Kemp and Judith Squires. Oxford: Oxford UP, 1997. 246-49. Print.

Payant, Katherine, B. Becoming and Bonding: Contemporary Feminism and Popular Fiction by American Women Writers. Westport, CT: Greenwood, 1993. Print.

Piercy, Marge. Woman on the Edge of Time. New York: Ballantine, 1991. Print.

Russ, Joanna. The Female Man. Boston: Beacon, 1986. Print.

Sargisson, Lucy. "Contemporary Feminist Utopianism. Practicing Utopia on Utopia." Literature and the Political Imagination. Ed. John Horton and Andrea T. Baumeister. New York: Routledge, 1996. 238-55. Print.

Shands, Kerstin W. The Repair of The World. The Novels of Marge Piercy. Westport, CT: Greenwood, 1994. Print.

Teslenko, Tatiana. Feminist Utopian Novels of the 1970s: Joanna Russ $\varepsilon$ Dorothy Bryant. New York: Routledge, 2003. Print.

Walker, Nancy A. Feminist Alternatives: Irony and Fantasy in the Contemporary Novel by Women. Jackson: UP of Mississippi, 1990. Print. 